\title{
Technical and Business Undergraduates' Self-Efficacy in Entrepreneurship
}

\author{
Zullina H. Shaari, Amzairi Amar, Azamudin Badri Harun, and Mohamed Radzi Zainol
}

\begin{abstract}
This paper examined how technical and business undergraduates perceive their ability to cope, perform and be successful in entrepreneurship. Previous research findings suggest that entrepreneurial intentions and actions are affected by individuals' self-esteem or self-efficacy pertaining to the self-confidence and perceived competency in business affairs. Perceived competence often refers to knowledge, skills and behavior, which are considered as the antecedence of self-confidence. As such, business students may be assumed to have higher self-esteem in business affairs than non-business students. However, little is known whether or not this assumption is valid. To address this issue, a set of questionnaire were distributed to technical and business undergraduates at two higher learning institutions to gauge their level of self-efficacy in business affairs. The study aims to explain the relationships between the component of individuals' self-efficacy, background and the entrepreneurial intention of technical and business undergraduates. The findings revealed that individuals' self-efficacy correlated with their training, but not with their informal entrepreneurship exposure and entrepreneurship intentions. The results also indicate that business and non-business students differ in one of the attitude components of self-efficacy.
\end{abstract}

Index Terms-Attitude, entrepreneurship, self-efficacy, self-esteem.

\section{INTRODUCTION}

Individuals' attitude has been argued to be more predictive of entrepreneur intention than personal characteristics or demographics. This argument has led to the development of the Entrepreneurship Attitude Orientation (EAO) scale (achievement, innovation, personal control and self-esteem) used in a survey among 54 entrepreneurs and 57 non-entrepreneurs [1]. The scale was able to accurately predict entrepreneur classification in 77 percent of cases [1]. Since its development, a number of other researchers used the scale to either describe the respondents' attitude towards entrepreneurship or predict respondents' entrepreneurial intent. For example, surveys conducted among undergraduates of various disciplines in Austria revealed that attitude had significant effect on entrepreneurial intent [2] Another study revealed that business undergraduates of varying discipline majors in Malaysia differed significantly in two subscales of the EAO, namely, self-esteem and personal control [3].

Manuscript received October 1, 2013; revised December 10, 2013. This work was supported in part by the Universiti Teknologi PETRONAS (UTP) and Politeknik Ungku Omar (PUO), Malaysia.

The authors are with the Department of Management and Humanities, UTP (e-mail:

amzairi_amar@petronas.com.my,

mradzi_zainol@petronas.com.my).
The self-esteem of the EAO is "pertaining to the self-confidence and perceived competency of an individual in conjunction with his or her business affairs" [1] and closely represents the concept of 'generalized self-efficacy'. The concept refers to individuals' estimate of their 'fundamental ability to cope, perform and be successful' and was found to be positively related to job performance [4]. Generalized self-efficacy is implied significant to influence an entrepreneur in engaging in innovative action, adopting a proactive stance and taking risks. [5]-[7]. Such ability is often developed gradually through experience [4] and is reinforced by past achievements [8]. Similarly, self-perceived competence represents acquired knowledge and learnt skills and behavior of entrepreneurs. This competence was considered the antecedent of self-efficacy [9] and found to be positively associated with venture performance or growth [10], [11]. In essence, the two dimensions of EAO self-esteem (self-confidence and perceived competence) clearly reflect the self-efficacy. The EAO subscale has 3 attitude components namely affect (emotion), cognition (thinking) and conation (behavior).

The most recent review on entrepreneurship suggests that self-efficacy is one of the many entrepreneurs' attitudes and personal characteristics [12]. Since self-efficacy in business affairs is often enhanced through developing competency, numerous universities have introduced entrepreneurship programs to students and assessed the impact of such programs. For example, a recently published study on the role of entrepreneurship education revealed that entrepreneurship education had positive impact on entrepreneurship intentions among students of 10 universities in China [13]. The study also indicated that students of technical universities had higher entrepreneurship intentions than students of other universities. These findings imply that formal exposure (entrepreneurship education) provides the relevant competency (knowledge and skills), and triggers entrepreneurship intent among students.

Meanwhile, other studies not investigating the impact of entrepreneurship education, explained the relationship between self-efficacy and entrepreneurship intentions. Among US business students, self-efficacy was found having negative correlation with attitude towards entrepreneurship and correlated negatively to personality variables such as entrepreneurs' ingenuity, perseverance, variety seeking and strong judgment [14], [15]. Surveys among secondary school students and university undergraduates in Malaysia revealed that self-efficacy had significant and positive relationship with entrepreneurship intention [16]-[18]. However, a study among participating US entrepreneurs revealed that cognition for self-efficacy in entrepreneurship was moderated by entrepreneurs' dispositional attributes [19].

The findings of these previous studies suggest that the role 
of self-efficacy or self-esteem may subject itself to a continuing debate among researchers of entrepreneurship. Perhaps, self-efficacy among undergraduates needs to be investigated further to gain better understanding of the role of each attitudinal component (cognition, behavior and affect) in influencing the overall self-efficacy in business affairs.

While most researchers have focused on investigating self-efficacy of business undergraduates, youths and participating entrepreneurs, a very limited research examined the same aspect among technical undergraduates. Little is known what level of self-efficacy in business affairs that technical students have, whether their level of self-efficacy is similar or different from business students, which aspect of attitude component has a significant impact on self-efficacy, and whether their self-efficacy and entrepreneurial background influence entrepreneurial intent. In order to address these gaps, the study investigated the relationship between self-efficacy in business affairs, the entrepreneurship background, and the entrepreneurship intention of technical undergraduates and compared them with business students.

\section{Methodology}

Faculty members teaching undergraduate courses collected 114 completed questionnaires from participants at 2 institutions of higher learning. Sixty two (16 male and 46 female; 61 Malay and 1 Chinese) were business students representing 31 per cent of business club members at a polytechnic. Fifty two (41 male and 11 female; 32 Malay, 2 Chinese, 6 Indian and 12 others) were technical students undertaking one compulsory management course at a private university representing 25 per cent of the total number of students taking the same course. These participants were 19 to 26 year-old second year students at the respective universities. Questionnaire completion was entirely voluntary and no identifying information was recorded.

Self-efficacy was measured with the EAO survey instrument [1]. The EAO is theoretically well-grounded and provides a composite score based on perceived self-esteem in business (Cronbach's Alpha 0.73; self-confidence and perceived competency in business affairs). The EAO has participants responded using a seven-point Likert-type scale to items in terms of how much they agree with each statement, where 1 = strongly disagree and $7=$ strongly agree. Examples of items include: "I believe successful people handle themselves well at business gathering", 'I believe that to succeed in business it is important to get along with the people you work with" and "I usually perform very well on my part of any project I am involved with."

In addition to completing the EAO, participants provided demographic information including gender, age and ethnicity In order to measure exposure to and intention for entrepreneurial initiatives, two questions were asked related to this: (1) Do you have a family member or relative who is an entrepreneur? (2) Are you going to join business world once you have completed your current studies?

All hypotheses were tested using correlation and regression analyses, and a nonparametric test. The determinations of significance were based upon a $p<0.05$ standard [20], [21].

\section{RESUlTS AND DISCUSSION}

Nineteen (31\%) of the business students and 15 (29\%) of the technical students had either a family member or a relative who was an entrepreneur. Fifty two (84\%) of the business students whilst $40(78 \%)$ of the technical students have had the intention to get involved in business with most of them intended to do so within 5 years after graduation. The stark difference between both groups of participants was about $17(27 \%)$ of the business students compared to only 4 $(8 \%)$ of the technical students had the intention to venture into business activities immediately after graduation. These results appear to be consistent with the assumption of business students are likely to have higher level of self-efficacy in business affairs than technical students. However, the findings were subject to statistical analyses to either verify or defy the assumption.

The relationships among self-efficacy, the attitude components (cognition, behavior and affect) in business affairs, the entrepreneurship intention, and the entrepreneurship background (informal versus formal exposures) of technical and business undergraduates were investigated using Pearson correlations coefficient. Preliminary analyses were performed to ensure no violation of assumptions of normality, linearity, and homoscedasticity.

As illustrated in Table I, there were strong, positive correlations between self-efficacy and behavior, $r=0.71, n=$ $114, p=0.00$, and between self-efficacy and affect, $r=0.73$, $n=114, p=0.00$, with high levels of self-efficacy associated with high levels of individuals' behavioral and affective attitudes. However, no correlation was found between self-efficacy and cognition. This suggests that self-efficacy had no association with individuals' thinking or cognition. In other words, behavioral and affective attitudes appear to be more significant in predicting self-efficacy in business affairs than individuals' cognitive attitude.

TABLE I: CORRELATIONS

\begin{tabular}{|c|c|c|c|c|c|c|}
\hline & & & 1 & 2 & 3 & 4 \\
\hline \multirow{3}{*}{1} & \multirow{3}{*}{$\begin{array}{c}\text { Total } \\
\text { Cognition }\end{array}$} & $\begin{array}{l}\text { Pearson } \\
\text { Correlation }\end{array}$ & 1 & $-0.234 *$ & $-0.288 * *$ & 0.084 \\
\hline & & $\begin{array}{l}\text { Sig. } \\
\text { (2-tailed) }\end{array}$ & & 0.012 & 0.002 & 0.376 \\
\hline & & $N$ & 114 & 114 & 114 & 114 \\
\hline \multirow{3}{*}{2} & \multirow{3}{*}{$\begin{array}{c}\text { Total } \\
\text { Behavior }\end{array}$} & $\begin{array}{l}\text { Pearson } \\
\text { Correlation }\end{array}$ & $-0.234 *$ & 1 & $0.250 * *$ & $0.712 * *$ \\
\hline & & $\begin{array}{l}\text { Sig. } \\
\text { (2-tailed) }\end{array}$ & 0.012 & & 0.007 & 0.000 \\
\hline & & $N$ & 114 & 114 & 114 & 114 \\
\hline \multirow{3}{*}{3} & \multirow{3}{*}{$\begin{array}{c}\text { Total } \\
\text { Affect }\end{array}$} & $\begin{array}{l}\text { Pearson } \\
\text { Correlation }\end{array}$ & $-0.288^{* * *}$ & $0.250 * *$ & 1 & $0.731 * *$ \\
\hline & & $\begin{array}{l}\text { Sig. } \\
\text { (2-tailed) }\end{array}$ & 0.002 & 0.007 & & 0.000 \\
\hline & & $N$ & 114 & 114 & 114 & 114 \\
\hline \multirow{3}{*}{4} & \multirow{3}{*}{$\begin{array}{c}\text { Total } \\
\text { Perceived } \\
\text { Self- } \\
\text { Efficacy }\end{array}$} & $\begin{array}{l}\text { Pearson } \\
\text { Correlation }\end{array}$ & 0.084 & $0.712 * *$ & $0.731 * *$ & 1 \\
\hline & & $\begin{array}{l}\text { Sig. } \\
\text { (2-tailed) }\end{array}$ & 0.376 & 0.000 & 0.000 & \\
\hline & & $N$ & 114 & 114 & 114 & 114 \\
\hline
\end{tabular}

*. Correlation is significant at the 0.05 level (2-tailed).

$* *$. Correlation is significant at the 0.01 level (2-tailed).

Direct logistic regression was performed to assess the influence of the self-efficacy and the informal exposure to entrepreneurship on the likelihood that participants would involve in business. The model confined two independent 
variables (total self-efficacy and the informal exposure to entrepreneurship). As shown in Table II, the results indicated none of the two independent variables (self-efficacy and background) made a statistically significant contribution to the model. This suggests that the model was not able to distinguish between respondents who had entrepreneurship intention and did not.

TABLE II: LOGISTIC REGRESSION PREDICTING INTENTION

\begin{tabular}{|c|c|c|c|c|}
\hline & & Background & $\begin{array}{c}\text { Total } \\
\text { Self-Efficacy }\end{array}$ & Constant \\
\hline \multicolumn{2}{|c|}{ B } & 0.155 & -0.003 & -1.428 \\
\hline \multicolumn{2}{|c|}{ S.E } & 0.520 & 0.045 & 2.350 \\
\hline \multicolumn{2}{|c|}{ Wald } & 0.089 & 0.004 & 0.370 \\
\hline \multicolumn{2}{|c|}{$\mathrm{df}$} & 1 & 1 & 1 \\
\hline \multicolumn{2}{|c|}{ Sig. } & 0.765 & 0.949 & 0.543 \\
\hline \multicolumn{2}{|c|}{ Odds Ratio } & 1.168 & 0.997 & 0.240 \\
\hline \multirow{2}{*}{$\begin{array}{l}95 \% \text { C.I. } \\
\text { for Odds } \\
\text { Ratio }\end{array}$} & Lower & 0.421 & 0.913 & \\
\hline & Upper & 3.238 & 1.089 & \\
\hline
\end{tabular}

In order to compare the self-efficacy of the two groups (business versus technical students), a nonparametric statistical analysis, Kruskal-Wallis Test, was conducted to compare medians of attitude components (cognition, behavior and affect). As shown in Table III, the test revealed a statistically significant difference in self-efficacy between the two groups (Gp1, $n=62$ : business students, Gp2, $n=52$ : technical students) $\boldsymbol{4}^{2}(1, n=114)=8.69, p=.00$. The technical student group recorded higher median score $(M d=$ 53 ) than the business student group with median value of 50. For each attitude component, only the behavioral attitude was statistically significant different between the groups with $p$ $=9.82$ with median score of 16.5 for technical students and 14 for business students. These results suggest that business and technical students possessed almost equal levels of cognitive and affective attitudes toward entrepreneurship, but differed in terms of behavioral attitude. The median of business students' behavioral attitude of self-efficacy was lower than that of technical students, though more business students (27\%) expressed higher likelihood to venture into business upon graduation than technical students (4\%). This difference suggests that behavioral attitude may represent the differentiating factor between business and technical students in their self-efficacy in business affairs.

TABLE III: TEST STATISTICS FOR ATTITUDE COMPONENTS OF SELF EFFICACY AND TOTAL OF SELF EFFICACY IN BUSINESS AFFAIRS BETWEEN BUSINESS AND TECHNICAL STUDENTS

\begin{tabular}{lccc}
\hline \hline Attitude & Chi-Square & df & Asymp. Sig \\
\hline Cognition & 0.655 & 1 & 0.418 \\
\cline { 2 - 4 } & 19.0000 & 113 & \\
\hline Behavior & 9.824 & 1 & 0.002 \\
\hline Affect & 15.0000 & 113 & \\
\cline { 2 - 4 } & 0.921 & 1 & 0.337 \\
\hline Self-Efficacy & 17.0000 & 113 & \\
\cline { 2 - 4 } & 8.688 & 1 & 0.003 \\
\hline \hline
\end{tabular}

\section{CONCLUSION}

In summary, while informal and formal exposure to entrepreneurship and self-efficacy may be assumed to enhance the likelihood of students to venture into business affairs, the current study revealed that such an assumption requires more robust empirical evidence. Besides, though the EAO had been considered reliable in measuring individuals' attitude towards entrepreneurship, findings of this study suggest that not all attitudinal components of self-efficacy is highly associated with the overall self-efficacy in business affairs. The cognitive component was not highly associated with the self-efficacy, but the behavioral and affective components appeared to be positively linked to overall self-efficacy. These findings seem consistent with findings that suggest individuals' cognition was moderated by individual differences [18]. The individual differences are often manifested through individuals' behaviors and emotions demonstratively. Of all attitudinal components in self-efficacy, technical students appear to have higher level of behavioral attitude in business affairs than business students. In other words, exposures to entrepreneurship do not necessarily contribute to overall perceived self-confidence and competence in business affairs. As such, perceived self-confidence and competence in entrepreneurship may not be necessarily triggered through entrepreneurship exposures, but rather reside in individuals' affective and behavioral attitudes developed over time.

\section{ACKNOWLEDGMENT}

The authors would like to thank Universiti Teknologi PETRONAS and Politeknik Ungku Omar, Perak, Malaysia and graduate assistants for providing the facilities and support to complete this research.

\section{REFERENCES}

[1] P. B. Robinson, D. V. Stimpson, J. C. Huefner, and H. K. Hunt, “An attitude approach to the prediction of entrepreneurship," Entrepreneurship Theory and Practice, Summer, pp. 13-31, 1991.

[2] E. J. Schwarz, M. A. Wdowiak, D. A. A. Jarz, and R. J. Breitenecker, "The effects of attitudes and perceived environment conditions on students' entrepreneurial intent: An Austrian perspective," Education and Training, vol. 51, no. 4, pp. 272-291, 2009.

[3] M. N. M. Shariff and M. B. Saud, "An attitude approach to the prediction of entrepreneurship on students at institution of higher learning in Malaysia," International Journal of Business and Management, vol. 4, no. 4, pp. 129-135, 2009.

[4] T. A. Judge and J. E. Bono, "Relationship of core self-evaluations traits-self-esteem, generalized self-efficacy, locus of control, and emotional stability-with job satisfaction and job performance: A meta-analysis," Journal of Applied Psychology, vol. 86, no. 1, pp. 80-92, 2001

[5] S. G. Boyd and G. S. Vozikis, "The influence of self-efficacy on the development of entrepreneurial intentions and actions," Entrepreneurship Theory and Practice, vol. 18, no. 4, pp. 63-77, 1994.

[6] J. M. L. Poon, R. A. Ainuddin, and S. Haji Junit, "Effects of self-concepts traits and entrepreneurial orientation on firm performance," International Small Business Journal, vol. 24, no 1, pp. 61-80, 2006.

[7] A. Bandura, "Reflections on self-efficacy," Advances in Behavioral Research and Therapy, vol. 1, no. 4, pp. 237-269, 1978.

[8] L. Herron and H. J. Sapienza, "The entrepreneur and the initiation of new venture launch activities," Entrepreneurship Theory and Practice, vol. 17, no. 1, pp. 49-55, 1992.

[9] H. Zhao, S. E. Siebert, and G. E. Hills, "The mediating role of self-efficacy in the development of entrepreneurial intentions," Journal of Applied Psychology, vol. 90, no. 6, pp. 1265-1272, 2005.

[10] J. R. Baum and E. A. Locke, "The relationship of entrepreneurial traits, skill, and motivation to subsequent venture growth," Journal of Applied Psychology, vol. 89, no. 4, pp. 587-598, 2004.

[11] G. N. Chandler and E. Jansen, "The founder's self-assessed competence and venture performance," Journal of Business Venturing, vol. 7, no. 3, pp. 223-236, 1992. 
[12] R. K. Jain, "Entrepreneurial competencies: A meta-analysis and comprehensive conceptualization for future research," Vision: The Journal of Business Perspective," vol. 15, no. 2, pp. 127-152, 2011.

[13] Y. Zhang, G. Duysters, and M. Cloodt. (January 2013). The role of entrepreneurship education as predictor of university students' entrepreneurial intention. International Entrepreneurship and Management Journal. [Online]. Available: http://link.springer.com/article/10.1007/s11365-012-0246-z

[14] M. L. Harris and S. G. Gibson, "A connection between personality and entrepreneurial attitudes: Evidence for U.S. business students," in Small Business Instutite ${ }^{\circledR}$ National Proceedings, vol. 33, no. 1, pp. 9-22, 2009.

[15] M. L. Harris and S. G. Gibson, "Examining the entrepreneurial attitudes of us business students," Education and Training, vol. 50, no. 7, pp. 568-581, 2008

[16] Z. A. L. Pihie and A. Bagheri, "Malay secondary students' entrepreneurial attitude and entrepreneurial efficacy: A descriptive study," Journal of Applied Sciences, vol. 11, no. 2, pp. 316-322, 2011.

[17] Z. A. L. Pihie and A. Bagheri, "Malay students' entrepreneurial attitude and entrepreneurial efficacy in vocational and technical secondary schools of Malaysia," Pertanika Journal of Social Science and Humanities, vol. 19, no. 2, pp. 433-447, 2011.

[18] N. Ismail, N. Jaffar, and S. H. Tan, "Using EAO model to predict the self-employment intentions among the universities' undergraduates in Malaysia," International Journal of Trade, Economics and Finance, vol. 4, no. 5, pp. 282-287, October 2013.

[19] P. Arora, J. M. Haynie, and G. A. Laurence, "Counterfactual thinking and entrepreneurial self-efficacy: The moderating role of self-esteem and dispositional affect," Entrepreneurship Theory and Practice, vol. 37, no. 2, pp. 359-384, 2013.

[20] J. W. Cohen, Statistical Power Analysis for the Behavioral Sciences, $2^{\text {nd }}$ ed., Hillsdale, New Jersey: Lawrence Erlbaum Associates, 1988.
[21] J. Pallant, SPSS Survival Manual, $4^{\text {th }}$ ed., Crown Nest: Allen and Unwin, 2011.

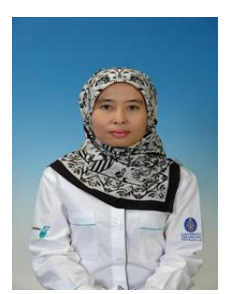

Zullina H. Shaari is a faculty member of Universiti Teknologi Petronas (UTP). She was born in Malaysia on 5 August. H. Shaari is completing a $\mathrm{Ph} . \mathrm{D}$. in Marketing with the University of Sydney, Australia. She was granted an MSc from the University of Stirling, UK in 1998 and a BBA from the University of North Texas, USA in 1989. She is currently a lecturer at the Universiti Teknologi Petronas, Malaysia. She started being an academic at the Universiti Teknologi Mara, Terengganu Campus, Malaysia after leaving an auditing career at a KPMG branch in Malaysia.

Ms H. Shaari is a member of the international association of business communicators (IABC) and an associate member of Malaysian institute of management (MIM).

Amzairi Amar is a senior lecturer at UTP possessing an MBA and a BBA from a US university and more than 10 years in financial and banking industry. He has been actively involved in entrepreneurial training and consultancy work.

Azamudin Badri Harun is a senior lecturer at UTP currently undertaking his $\mathrm{PhD}$ with a university in Malaysia on a part time basis. He worked with Petronas, Universiti Teknologi Malaysia and other industries prior to joining academia.

Mohammad Radzi Zainol is a senior lecturer at UTP currently enrolled as a part time doctoral student with a university in Malaysia. He has extensive experience at senior management level in various industries including services, automotives, plantations and chemicals. 